in writing: 'Mais alors que nous possédons au Congo belge diverses études déjà très poussées sur les tons des mots, si essentiels pour la signification dans les langues bantoues, on ne trouve encore en Afrique du Sud aucune langue pour laquelle les tons sont publiés.' He asks for the proscription of Swahili and 'the soi-disant lingala' in Belgian Congo, in the interest of civilization.

The Bulletin de l'Institut d'Études Centrafricaines is published at Brazzaville under the patronage of the Government-General of French Equatorial Africa. Its aim is well expressed in an introductory note. In these days when economics is so dominant there is a great temptation to regard everything as rather negligible that does not bear upon production and the standard of living. "Ce serait une erreur. La connaissance approfondie et rationnelle d'un pays est l'un des instruments indispensables de l'action. Et par connaissance rationnelle il faut entendre une connaissance qui va à la source et au détail.' The Bulletin therefore will seek to obtain and spread abroad precise detailed information about the peoples, the geography, the material resources of A.E.F. The first number, of i 2 closely printed pages, contains several articles of anthropological interest, from one of which we give an abstract on pages $\times 88-9$.

Afroamerica is the organ of the International Institute of Afroamerican studies which was set up in October 1943 after the first Congress of Interamerican Demography held in Mexico. The aim of the Institute is to study the Negro populations of America in their biological and cultural aspects. Its journal is to be published twice a year; it is printed in Mexico.

A fourth new journal has the distinction of being (apart from quotations of French writers) entirely written and edited by Africans. It is entitled Genese and is the bulletin of an Association whose active members are all old students of the École William Ponty on the island of Goree. It is published at Rufisque in Senegal. Its aim is to help in carrying out the objects of the Association, viz. to link the Old Boys in friendly union, to conserve and perfect their general and professional attainments and (this is significant) "to make Franco-African culture an ever richer reality'. This first number affords pleasing evidence of interest in things African. One section is devoted to members' contributions under the rubric ' $\mathrm{La}$ Voix de l'Afrique'-tales, songs, essays; and an appeal is made for the collection of stories 'from the aged lips which soon will not open again'. The French text is printed of a short play performed at the Dakar meeting of the International Congress of Africanists; this is a rendering of a Susu fabliau, ' Eh bien! mais oui'. There are poems in French from one of which (by Ouezzin Coulibaly) we quote these lines. They are written in praise of the School:

\footnotetext{
A moi qui n'avais rien, Ponty a tout donné,

Travail et joie et ce bonheur d'être l'aîné

De mille adolescents d'âme fière et ardente,

Sportifs et travailleurs, et toujours prêts au don

De soi pour tous; de mes jeunes frères que hante

Le courageux souci de jamais dire "non'.
}

\title{
Applied Anthropology
}

After reading Dr. Evans-Pritchard's article in the April number of Africa, Dr. Margaret Read wrote to us as follows:

'Dr. Evans-Pritchard has thrown down the glove on the issue of colonial governments and the use they make, or could make, of anthropologists. He has at the same time stated with emphasis that the two primary tasks before anthropologists to-day are research and teaching. With this latter statement no anthropologist would quarrel. Whether he is teaching or doing research work, he is always coming up against the limitations of the existing field of knowledge, both extensively in the study of societies of similar and con- 
trasting types, and intensively in the elucidation of fundamental problems in anthropology and the allied social sciences.

'One of the main difficulties an anthropologist has to accept as part of his fate is that in his research work he cannot make use of a laboratory technique such as is common to the physical and natural sciences, and even to some extent to psychology. He cannot therefore, in a corner of a "lab ", try out experiments over and over again to test his hypothesis until he gets a satisfactory result. It follows that an anthropologist cannot take his colleagues to his research work-he has to bring it to them, in terms of his own observations and collected data. This makes necessarily for a much more individualist attitude towards research, and perhaps accounts for the apparent lack of co-ordination in the research field, where each successive research worker picks out his own area and dominant problems, and works away at them in more or less splendid isolation.

'This kind of situation, in a science where shortage of trained man-power is the outstanding characteristic, lends support to Dr. Evans-Pritchard's plea for centralising research in the universities. A few years ago ${ }^{\mathrm{I}}$ an article in the British Medical Journal discussed the relation between strategy and tactics in research, and emphasised the need for a co-ordinated planning of the field as the strategic measure necessary before the tactics could be brought into play. It is this strategic planning which should be the role of the universities in a relatively new science such as anthropology, especially as the time factor-the rapid disappearance of certain primitive societies-cannot be ignored. Having said this, and perhaps gained general agreement to the idea, one has to recognise immediately the absence of co-ordination between the universities both in covering the field from the angle of teaching facilities and in planning research.

'There are signs that some such co-ordination in research may be achieved in the strictly colonial field through the Social Science Research Council of the British Colonial Office. But Dr. Evans-Pritchard has warned us that the colonial governments have their eyes mainly, and quite naturally, on practical problems, and the tendency will therefore be to give greatest encouragement to research which seems to yield fairly immediate practical returns.

"The familiar use of a phrase like "practical problems" can sometimes obscure an important issue. The general line of Dr. Evans-Pritchard's lecture was the application of anthropology to the problems of colonial governments vis-à-vis primitive peoples. An essential element in such problems is that of the changing primitive society, and this is at the same time a fundamental research problem and a practical issue. Dr. Evans-Pritchard sees the urgent problems mainly in the field of administration. In one sense, of course, administrative officers are tesponsible for all types of change and adjustment in the lives of primitive peoples. But officials and other workers in the fields of agriculture, education, public health, and welfare are even more directly concerned with the results of their influence on primitive life, and in their training the importance of anthropological knowledge is often ignored. It is true that the administrative officer has more opportunity of seeing tribal life as a whole. But the fact that agricultural officers, by insisting on new methods of cultivation, may be upsetting the whole balance of a primitive economy, is surely all the more reason why they should understand the interrelatedness of all aspects of tribal life, and the consequences of drastic economic and social changes, through having had some anthropological training.'

\section{Another Vien of Applied Anthropology}

Dr. S. F. NADEL is well known to readers of Africa. After holding a Research Fellowship of the Institute and producing $A$ Black Byzantium as a result of his work in Nigeria, he was

I ${ }_{77}$ April 1943. 